\title{
Giving Lemna Minor and Mud to the Growth of Tubifex sp.
}

\author{
Mahendra $^{1}$, Doni Damara ${ }^{2}$, Mursidatun Nufus ${ }^{2}$, Vira Riana Putri ${ }^{1}$ \\ ${ }^{1}$ Aquaculture Study Program, Faculty of Fisheries and Marine Science, Teuku Umar University, Aceh, \\ Indonesia \\ ${ }^{2}$ Fisheries Study Program, Faculty of Fisheries and Marine Science, Teuku Umar University, Aceh, Indonesia \\ mahendra@utu.ac.id
}

\begin{abstract}
This study aims to determine the effect of the use of a combination of lemna minor substrates and mud on the biomass of the population of Tubifex sp. This research is experimental, with a completely randomized design (CRD), with five levels of treatment $P 1=$ $100 \%$ (lemna minor $)+2,000 \mathrm{gr}$ (mud), $P 2=75 \%$ (lemna minor $)+2,000 \mathrm{gr}(\mathrm{mud}), \mathrm{P3}=50$ $\%$ (lemna minor ) $+2,000 \mathrm{gr}(\mathrm{mud}), \mathrm{P} 4=25 \%$ (lemna minor $)+2,000 \mathrm{gr}$ (mud), P5 =0\% (lemna minor) $+2,000 \mathrm{gr}(\mathrm{mud})$. Data obtained from research results in analysis of variance (ANOVA) and in further testing with the Smallest Significant Difference test. The main parameters observed were the number of population and biomass of Tubifex sp. The results of the study showed that the combination of Lemna minor substrate and mud significantly ( $p$ $<0.05)$ on the growth of biomass and the population of Tubifex sp. The best results were found in the treatment with the treatment formulation $P 1=100 \%$ (lemna minor ) $+2,000 \mathrm{gr}$ (mud) which produced a population of 6,250 ind / gr and biomass $8.60 \mathrm{gr} / \mathrm{m} 2$.
\end{abstract}

Keywords : Tubifex sp; lemna minor; population

\section{Introduction}

Silk worms (Tubifex sp.) are one of the natural foods needed for aquaculture. Tubifex $\mathrm{sp}$. is a water animal clustered in a flow of water that is not so heavy. Tubifex sp. live by immersing yourself in the soil layer. There are several factors that support silk worm habitat including sludge deposits and piles of organic matter (Cartwright, 2004).

Tubifex worms are included as a group of water worms, people generally know the name of silk worms, hair worms, blood worms or sewage worms. Silk worms or hair worms belong to the worm group (Tubifex sp). It is called a silk worm because this worm has a soft and very soft body like silk / hair.

Tubifex sp. has a size of $1-2 \mathrm{~cm}$ long with reddish color. This worm has a digestive tract in the form of a small gap from the mouth to the anus, consisting of 30-60 segments or segments. At first glance tubifex looks like a red colony waving because of its body color. This species has a digestive tract in the form of a small gap starting from the mouth to the anus. These silk worms (Tubifex sp) live in colonies. Most Tubifex make tubes in mud on the bottom of the water, where the posterior end of the body protrudes from the tube and moves back and forth while waving actively in the water, causing water circulation and worms to get oxygen through the body surface. Vibration in the posterior part of the body from Tubifex can help with respiratory function.

Silk worms (Tubifex sp) include hermaphrodite organisms. In one individual this organism has 2 (two) genitals and multiplies by laying eggs from mature eggs. Silk worm eggs (Tubifex sp) occur inside the cocoon, which is an ovoid building, $1 \mathrm{~mm}$ long and $0.7 \mathrm{~mm}$ in diameter. Eggs in the body undergo division, then develop into segments. After a few days the silk worm embryo (Tubifex sp) will come out of the cocoon. A baby that can produce cocoons and remove eggs that hatch into tubifex has an age of about 40-45 days. The number of eggs in each cocoon ranges from 4-5 grains. The time needed to breed eggs in the cocoon until it hatches into a silk worm embryo takes around 10-12 days. The life cycle of silk worms from eggs, hatching to adulthood and removing cocoons takes about 50-57 days. 
Tubifex worms mostly live in fresh waters where the water is clear and slightly flowing. The preferred water base is muddy and contains organic matter. The main food is organic ingredients that have decomposed and settled in the bottom of the water.

Silk worms (Tubifex sp) are generally found in border water areas such as areas where heavy organic matter pollution occurs, sediment deposition areas and oligotropic waters. This Tubifex sp worm species can tolerate waters with $10 \mathrm{ppt}$ salinity. Two factors that support the living habitat of silk worms (Tubifex sp) are mud deposits and a large pile of organic matter.

Tubifex sp. can live in various habitats. They usually bury themselves in mud or make burrows in the mud. They make tubes that are settled or can be carried around. The tube is made from mud, mineral grains or rubbish which are attached to one another by mucus. But its presence in the waters is often said to be an indicator of water pollution. Tubifex develops well in media which have dissolved oxygen content ranging from $2.75-5$, ammonia content $<1$ ppm, water temperature ranging from $28-30^{\circ} \mathrm{C}$ and $\mathrm{pH}$ of water between 6-8.

As a feed for freshwater ornamental fish, this worm has an important role. Feed from worms can stimulate fish growth much faster than other types of natural feed. This is due to the high fat content and protein of the worm. This worm has a protein content of $51.9 \%$, carbobydrate $20.3 \%$, fat $22.3 \%$, and ash $5.3 \%$. While the amino acids making up the protein are also complete.

Silk worms are easily found in Indonesia, also known as Hair Worms, popular as animal feed, namely fish. Therefore, the cultivation of Silkworms is increasingly demanded and has even become one of the economic opportunities that can reap many benefits. In general, these worms are obtained from the wild and are culturally cultivated on a small or large scale depending on the media used, whether using media in the ground, cement tanks or tarpaulin pools.

The success of silkworm cultivation is largely determined by the culture media used. One additional ingredient in Tubfex sp. Culture media. the potential is Lemna minor. Lemna minor is a natural source of protein which has a high protein content of $15-40 \%$ (Landesman et al., 2006).

Lemna minor has been used for several years as a nutrient substitute for wastewater and simultaneously producing food for livestock, fish and poultry. In addition, Lemna minor is easily harvested from the surface of the water and can be produced as high protein flour (Yilmaz et al., 2004). Compared to other plants, Lemna minor leaves contain as much as 5\% fine fiber in the weight of the cultivated plants. Lemna minor has a crude protein content of $37.6 \%$ and $9.3 \%$ fiber, so this plant has the potential to be used as fish feed (Culley et al., 1981).

Solution to meet the needs of Tubifex sp. this is by developing Tubifex sp. with the aim that the needs of Tubifex sp as natural fish food can be fulfilled. So it is necessary to cultivate Tubifex sp. good and sustainable way to meet the fish's natural feed needs.

\subsection{Experimental Design}

\section{Methodology}

The method used in this study is the experimental method and the design used is a Completely Randomized Design (CRD) consisting of 5 treatments with 3 replications each. The treatment of each material used in this study includes:

$\mathrm{P} 1=100 \%$ (lemna minor $)+2,000 \mathrm{gr}$ (mud)

$\mathrm{P} 2=75 \%$ (lemna minor $)+2,000$ gr (mud) 
$\mathrm{P} 3=50 \%$ (lemna minor $)+2,000 \mathrm{gr}$ (mud)

$\mathrm{P} 4=25 \%$ (lemna minor $)+2,000 \mathrm{gr}$ (mud)

$\mathrm{P} 5=0 \%$ (lemna minor $)+2,000 \mathrm{gr}$ (mud)

\subsection{Research Procedure}

Containers used for the cultivation of Tubifex sp. measuring $27 \times 18 \mathrm{~cm} 2$ which is modified with inlet and outlet channels with recirculation systems that reuse water that has been used by continuously rotating water through an intermediate filter or into a container.

The substrate used is of two kinds, namely lemna minor and sandy mud. Lemna minor is used fermented, while the sludge used comes from the rice field area first separated from the garbage and benthic organisms, then dried and sifted until smooth. Furthermore, the production of live media of silk worms according to the treatment. The dosage for each treatment is 500 grams of lemna minor and 2000 grams of sandy mud. The dosage is used to obtain a height of $4 \mathrm{~cm}$ cultivation media (Safrina et al., 2015). Furthermore, filling the container water is left for 10 days. The stocking density used is 10 grams.

Harvest is done after the maintenance period of Tubifex sp. for 50 days. How to harvest is done by filtering the media with a filter in the flow of flowing water. The results are left in the container and covered with black plastic for 30 minutes to make it easier for the separation process. Tubifex sp. which has been obtained and then rinsed with water to clean it from mud. Tubifex sp. which has been harvested and then taken and calculated.

Population amount of Tubifex sp. determined by counting directly from sampling, the sample taken in this study is to calculate the population of Tubifex $\mathrm{sp}$. 1 gram and then converted to the amount of Tubifex sp. biomass. obtained from each treatment (Cahyono et al., 2015).

\section{Discussion}

\subsection{Population of Tubifex sp}

The results of the population obtained after the maintenance period of Tubifex sp for 50 days of maintenance can be presented in Figure 1.

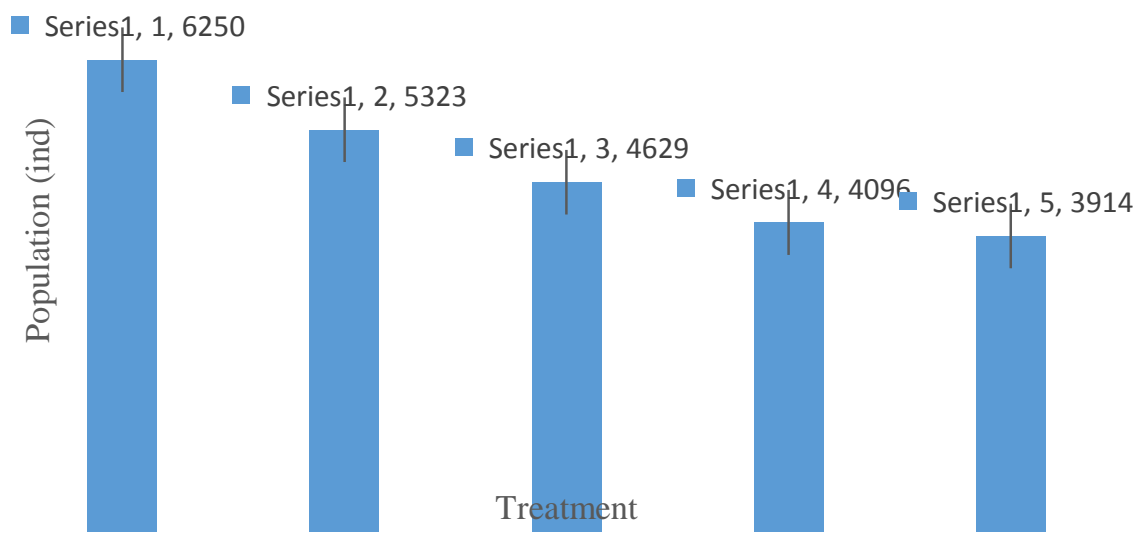

Based on the smallest real difference test (BNT) showed that enrichment of Tubifex sp. Culture media. with the combination of Lemna minor and sandy mud substrate has a very significant effect $(\mathrm{P}<0.05)$ on the population. It is presumed that the nutritional content of the 
lemna minor fermented can meet the life needs of Tubifex sp. The population is closely related to the reproductive process, in addition to the quantity of food available, the quality of food must also be considered, so that it can meet the needs of both growth and reproduction.

Differences in population numbers are also suspected because food availability in each treatment is not the same. This is in accordance with Findy's statement (2011), Tubifex sp. need food for growth and reproduction. Hadiroseyani (2007) added that population level differences were influenced by the content of protein and fat in the fertilizer feed of Tubifex sp. this shows that the use of a combination of Lemna minor fermentation substrate and mud effectively increases the population of Tubifex sp.

\subsection{Biomass Tubifex sp}

The result of absolute biomass growth of Tubifex sp. for 50 days maintenance is presented in Figure 2.

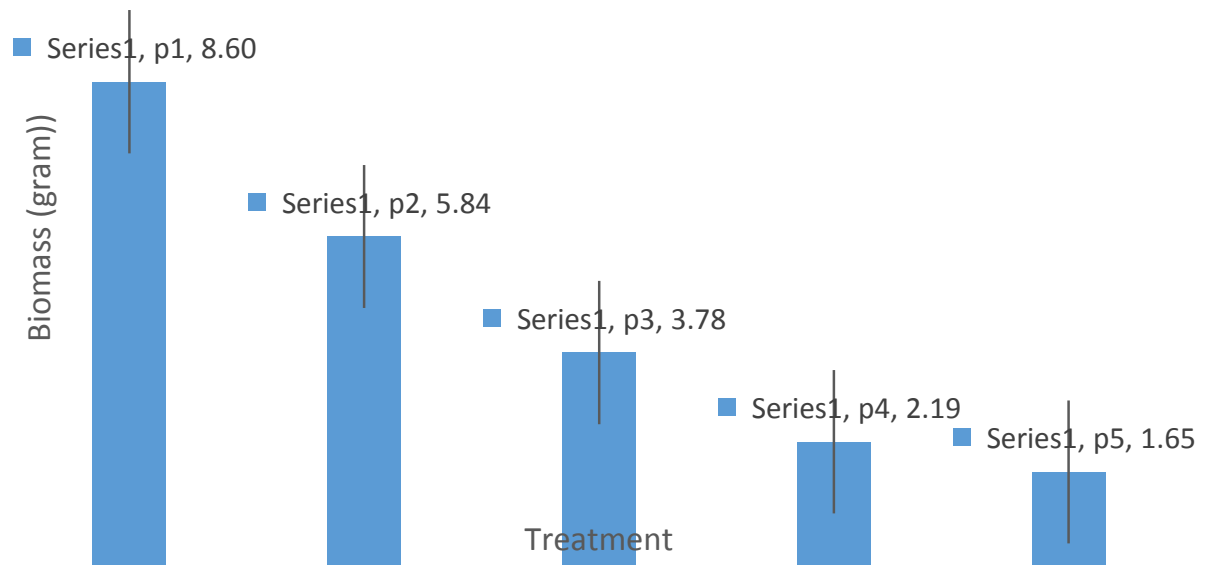

The high biomass in treatment 1 is thought to be because fertilizer in treatment 1 has a protein content in the cultivation medium, so that it can cause weight on Tubifex sp. relatively high. According to Syam et al. (2011), adding that the high organic matter in the media will increase the number of bacteria and organic particles resulting from decomposition by bacteria, so that it can increase the amount of food ingredients in the media that can affect the population and biomass of Tubifex sp. This is also in accordance with the statement of Febrianti (2004), organic matter contained in the media increases the number of bacteria and organic particles resulting from decomposition by bacteria can increase the availability of nutrients in the media which will affect the population and production of Tubifex sp.

\section{Conclusion}

The use of a combination of lemna minor and mud substrate media has an effect on the growth of Tubifex sp., Especially in the P1 $=100 \%$ (lemna minor) $+2,000$ gr (sand) media producing the highest population of 6,250 ind / gr and Tubifex sp. amounting to $8.60 \mathrm{gr}$. 


\section{References}

Cahyono, E. W., Hutabarat, J., dan Herawati, V. E. 2015. Pengaruh Pemberian Fermentasi Kotoran Burung Puyuh yang Berbeda Dalam Media Kultur Terhadap Kandungan Nutrisi dan Produksi Biomassa Cacing Sutra (Tubifex sp.). Journal of Aquaculture Management and Technology. 4 (4) : 127-135.

Cartwringht, D. 2004. Effect of Riparian Zone and Associanted Stream Subsrata on Tubifex tubifex. National Fish Health Research Laboratory. Kearnysville. USA.

Culley, D. D., Remjankova, E., Kvest, J., and Frey, J. B. 1981. Production Chemical Quality and Use of Duckweed (Lemnaceae) in Aquaculture, Waste Management and Animal Feed. J Worldmariculture Soc, 12.

Febrianti, D. 2004. Pengaruh Pemupukan Harian dengan Kotoran Ayam terhadap Pertumbuhan Populasi dan Biomassa Cacing Sutera (Limnodrillus). [Skripsi]. Fakultas Perikanan dan Ilmu Kelautan. Institut Pertanian Bogor.

Findy, S. 2011. Pengaruh Tingkat Pemberian Kotoran Sapi terhadap Pertumbuhan Biomassa Cacing Sutera. Departemen Budidaya Perairan Fakultas Perikanan dan Ilmu Kelautan. Institut Pertanian Bogor. Bogor.

Hadiroseyani, Y, Nurjariah, dan D. Wahjuningrum. 2007. Kelimpahan Bakteri dalam Budidaya Cacing Limnodrillus sp yang dipupuk Kotoran Ayam Hasil Fermentasi. Jurnal Akuakultur Indonesia. 6 (1): 79-87.

Landesman, L., Jiayang C., Yuri Y., and Jeremy G. 2006. Nutritional Value of Wastewater Grown Duckweed for Fish and Shrimp Feed. Nort Carolina State University: Department of Biological and Agricultural Engineering and Department of Forestry.

Safrina., Putri, B., dan Wijayanti, H. 2015. Pertumbuhan Cacing Sutra (Tubifex sp.) yang Dipelihara Pada Media Kulit Pisang Kepok (Musa paradisiaca) dan Lumpur Sawah. Jurnal Swasembada Pangan. 2 (1) : 520-525.

Syam, F. S., G. M. Novia. dan S. N. Kusumastuti. 2011. Efektivitas Pemupukan dengan Kotoran Ayam dalam Upaya Peningkatan Pertumbuhan Populasi dan Biomassa Cacing Sutera Limnodrilus sp. melalui Pemupukan Harian dan Hasil Fermentasi. Fakultas Perikanan dan Ilmu Kelautan. Institut Pertanian Bogor, Bogor.

Yilmaz, Erdal; Ihsan A.; Gŏkhan G. Use of duckwed, Lemna minor, as a protein feedstuff in practical diets for common carp, Cyprinuscarpio, fry. Journal of Fisheries and Aquatic Sciences.Vol. 4: 105-109. 